\title{
Springer-Verlag 1842 - 1999: a review essay
}

Citation for published version (APA):

Backhaus, J. G. (1999). Springer-Verlag 1842 - 1999: a review essay. METEOR, Maastricht University School of Business and Economics. METEOR Research Memorandum No. 012 https://doi.org/10.26481/umamet.1999012

Document status and date:

Published: 01/01/1999

DOI:

10.26481/umamet.1999012

Document Version:

Publisher's PDF, also known as Version of record

\section{Please check the document version of this publication:}

- A submitted manuscript is the version of the article upon submission and before peer-review. There can be important differences between the submitted version and the official published version of record.

People interested in the research are advised to contact the author for the final version of the publication, or visit the DOI to the publisher's website.

- The final author version and the galley proof are versions of the publication after peer review.

- The final published version features the final layout of the paper including the volume, issue and page numbers.

Link to publication

\footnotetext{
General rights rights.

- You may freely distribute the URL identifying the publication in the public portal. please follow below link for the End User Agreement:

www.umlib.nl/taverne-license

Take down policy

If you believe that this document breaches copyright please contact us at:

repository@maastrichtuniversity.nl

providing details and we will investigate your claim.
}

Copyright and moral rights for the publications made accessible in the public portal are retained by the authors and/or other copyright owners and it is a condition of accessing publications that users recognise and abide by the legal requirements associated with these

- Users may download and print one copy of any publication from the public portal for the purpose of private study or research.

- You may not further distribute the material or use it for any profit-making activity or commercial gain

If the publication is distributed under the terms of Article $25 \mathrm{fa}$ of the Dutch Copyright Act, indicated by the "Taverne" license above, 
Springer-Verlag 1842 - 1999: A Review Essay

\author{
Dr. Jürgen G. Backhaus \\ Professor of Public Finances \\ University Maastricht - AE \\ P.O. Box 616 \\ 6200 MD Maastricht \\ The Netherlands \\ tel: $+31-43-3883636$ \\ fax: $+31-43-3884878$ \\ e-mail: j.backhaus@algec.unimaas.nl
}

Prepared for the Business Library Review. 


\section{Abstract}

Therecent Bertelsmann buy-out of Springer ends 157 years of fiercely independent scholarly publishing. On Tuesday February 16, 1999, the European Commission decided that, although both companies are active in professional publishing, the takeover does not raise any competitive objections because they have different focuses in that (professional) market. "The market share increase through the merger is limited", the Commission said. "Consequently, the concentration has been declared compatible with the common market.'1 This review article recalls the formidable history of this science publisher and its role in helping establish entire fields of scienceand technology. In particular, therole of this independent privatelyheld publishing company in confronting attempts infringing upon academic freedom is being emphasized.

JEL codes: 128, L41, N44

keyword: science publishing 
On February 16, 1999, the European Commission allowed Bertelsmann'staking over the science publisher Springer-Verlag. Thus, a 157-year old privately-held company ceased to exist as an independent entity, a force that had shaped the landscape of scholarly publishing. Bertelsmann AG is the world's largest book publisher, and it is among the world's largest media companies. In the United States, it operates Random House Incorporated which includes imprints such as Bantam, Double Day, Villard, Random Houseand Knopf. Recently, Bertelsmann has also been a mover on the Internet. In the German language area, Bertelsmann is known for its book publishing networks, significant science publishing, but also interests in other visual media such as television. The Bertelsmann Foundation is a force in the German language cultural landscape.

Springer-Verlag is a very different entity. A privately-held science publisher, in its 157 year long history it has launched many scientific serials, journals and handbooks and thereby helped creating entire fields of scholarship. This has, of course, been done in an economically viable way. As we look at the history of this publisher2, we note however, that the close contacts between publisher and the scholarly authors helped create generally accessible scholarship where none had been before. This is true for such diverse fields as medicine, physics or technology.

I.

Springer-Verlag was founded in Berlin by Julius Springer (1817-1877) on his 25th birthday on May 10 in 1842. Julius Springer was the son of a prominent Berlin merchant (by patent of 1815), who lived from 1771 until 1836. His father hailed from an old Jewish family residing in Frankfurt an der Oder, where Julius Springer's grandfather had received a trading permit in 1764. Isidor Springer became a Prussian citizen in 1813. He participated in the wars of independence (against France) and returned highly decorated. Julius Springer received a thorough education on liberal principles under Ludwig Cauer (1792-1834) who followed Pestalotsy's precepts. He then learned the book trade, and, when starting his own firm, built this one systematically by cultivating close contacts with the pre-eminent cultural figures in Berlin and beyond. For instance, in 1852 he published Harriet Beecher Stowe's "Uncle Tom's Cabin" (in German). It became an enormous success. The house later turned to science publishing and grew steadily and impressively, always being closely tied into Germany's fateful history. We can look at this by marking the anniversaries. Originally, the anniversaries were, of course, just round birthdays of the founder. When the company turned 75, Germany was at war (1917), a sad time for science publishing. When the company turned 100, the country was at war again in 1942, and now Springer-Verlag was even threatened with annihilation. Fortunately, before loosing its independence several years later, the 150th anniversary was marked with publishing volume 1 of the history of this important house and institution in the history of science.

2 See Heinz Sarkowski, "Der Springer-Verlag: Stationen seiner Geschichte, Teil 1: 1842-1945", BerlinHeidelberg-New York: Springer-Verlag, 1992. The volume was published on the occasion of the 150th anniversary of the publishing house. 
II.

When the Nazis took over in 1933, freedom of academic teaching and research was immediately endangered. This was donethrough theinnocuously named Act on the Reconstitution of the Civil Service which put severe restrictions on the ability of nonAryans to function in the professions. The new leaders used a two-pronged approach. Part one was the equalization of all parts of society with a view to making each part of society function in the interest of the new political vision. This equalization (Gleichschaltung) was also to be introduced in the sciences, and in all of them. Publishers would then be allowed to operate as independent entities but under the strict regime of a state body. For instance, for publishing in physics journals, the Ministry of Propaganda wished to have a central office where all manuscripts would be refereed anonymously. Springer (by now Ferdinand Springer) strongly disagreed with this move: 'The journals will lose their specific face. They will lose their specific character and approach. It is impossible to calculate the business consequences of such a change." (p. 330) This discussion took place in November 1933. For medicine, already by mid-May, Springer was asked to remove all Jewish journal editors and ensure an Aryanization of the journal boards.

In fact, the whole publishing venture was now considered a Jewish enterprise. The medical profession had soon been equalized in the National-Socialist Physicians' Federation, and in that body's regional publication for Saxony an articleappeared by Martin Staemmler under the heading "Jewry in Medicine", claiming that the entire medical literature was almost exclusively in Jewish hands and dominated by the Jewish publishing house of Springer. (p. 341) Outraged, Ferdinand Springer rejected the charge of his publishing house to be Jewish. He pointed out that his greatgrandfather had already participated in the wars of independence, that his grandfather who had founded the publishing house had been a member of the board of Berlin's protestant church of St. Sophie, that his father had participated in the war of 1870-71 and that he himself as a captain had participated in the First World War. Staemmler retorted that these were not issues of religion but of race.

III.

It is clear from this part of the history of the publishing house that the Nazis' novel approach at establishing two classes of citizens based on racial principles took those affected off-guard. This is not only true for the scholars but also for the publishers. Many of the scholars of course left in a hurry, if they had a chance. Others, incredulous stayed behind and some, such as Franz Eulenburg paid the ultimate price 3 The universities were totally unprepared already for the equalization campaign. But the second part of the two-pronged strategy, the Aryanization, additionally weakened the intellectual institutions. Aryanization all of a sudden created two different classes of colleagues, one group personally and immediately endangered, another conceivably profiting from the poor fate of the former. Hence, the second group was likely, at least as far as some of its members were concerned, to go along with the new approach, certainly if those classified as state-citizens but

3Jürgen G. Backhaus, "Vier wissenschaftliche Biographien: Franz Eulenburg, Werner Hochwald, Emil Kauder, und Franz Hermann Mueller", Working paper, 96/002 
not as reich-citizens chose to leave without putting up a fight. While the state universities essentially caved in already during the first months, the German intellectual landscape, although characterized by a state monopoly in the institutions of higher education including the universities, had traditionally had a private organization of the publishing business. Never has there been a system of university presses in the German language area, and this fact proved to becrucial in continuing the fight against the totalitarian regime. Springer, along with such houses as Duncker \& Humblott, Van den Hoek \& Ruprecht and Mohr-Siebeck belong to those independent privately-held companies which could not easily be subjected to the two-pronged approach of equalization and Aryanization. Hence, the private sector organization of independent publishers proved to bean important element in the resistance to thetotalitarian regime. Oddlyenough, the international reputation of the publishers' list turned out to be a big blessing. Germany at the time was bereft of foreign exchange, and many a time the Central Bank intervened against the Ministry of Propaganda in order to ensure the continuation of books, journals and series that were important for export and thereby generating foreign exchange. The publisher, of course, made extensive use of this friction in thenew government. Hence, the President of the Central Bank since 1935, Hjalmar Schacht, to our surprise, became a patron of academic freedom under these peculiar circumstances. Forty-five percent of the total revenues of this publishing house even after the war had started in 1940 came from export. In 1942, the Nazis moved to take over the publishing house. The bounty had become too big. The areas of medicine and related fields were to be put into a publishing house for health sciences, and the technical parts were to be handed over to the publishing arm of the NationalSocialist Trade Union. In order to prevent this from happening, Ferdinand Springer turned the company over to Tönjes Lange and could write to the regulating institution of publishing (Reichsschrifttumskammer), on November 12, 1942 that he had resigned from all of his companies.

IV.

It is anybody's guess whether an independent publishing house of Springer can continue to exist within the panorama of Bertelsmann AG. Thestrict application of market concentration measures competently used by the European Commission does not take into account the specifics of scientific publishing and its dynamics in history. Big scientific woks can be collective efforts spanning generations, and heavy-handed or shortsighted tactics help littleto instill a sense of stewardship and trust on the parts of editors and authors respectively. Whether a dominant and farflung as well as by implication highly vulnerable company such as Bertelsmann could have resisted effectively attempts at Aryanization and equalization as did the independent publishing house of Springer is an issue that is not currently on the political agenda; yet is might be important to take it into account when analyzing markets for intellectual property from an industrial organization point of view. 